\title{
HPV in oral squamous cell carcinomas of a Brazilian population: amplification by PCR
}

\section{HPV em carcinoma epidermóide de boca em população brasileira: amplificação por PCR}

\author{
Elena Riet Correa Rivero* \\ Fabio Daumas Nunes**
}

\begin{abstract}
Human Papilomaviruses (HPV) are a group of viruses associated with benign and malignant lesions of cutaneous and mucosal epithelia. Some "high risk" HPV types, especially HPV 16 and 18, are strongly correlated with cervical and anogenital cancers and are also related to the genesis of oral squamous cell carcinomas (OSCC). The aim of this work was to investigate the incidence of HPV infection in 40 paraffin-embedded or fresh specimens of OSCC, using PCR amplification of the viral DNA. Literature based primers (GP5+/GP6+) were used in order to amplify HPV DNA from the L1 gene, present in more than 22 types of HPV. A condyloma case with HPV 16 and 18 detected by in situ hybridization was used as a positive control. Amplification of HPV was observed only in the positive control. No squamous cell carcinoma cases showed DNA viral amplification. Absence of HPV DNA amplification by PCR in the analyzed specimens of OSCCs suggests that this virus not always plays a role in the carcinogenesis process. Discrepancy with some studies found in the literature may be related to methodology or population differences.
\end{abstract}

DESCRIPTORS: Carcinoma, squamous cell; Polymerase chain reaction; Papillomavirus, human; Oncogenic viruses.

\begin{abstract}
RESUMO: O papilomavirus humano (HPV) constitui um grupo de vírus associados com lesões benignas e malignas do epitélio da pele e das mucosas. Alguns tipos de HPV, ditos oncogênicos, especialmente os HPVs 16 e 18, estão fortemente correlacionados com os cânceres cervical e anogenital, e também têm sido implicados na gênese do carcinoma epidermóide de boca. O objetivo deste estudo foi investigar a incidência de infecção pelo HPV, em 40 casos de carcinoma epidermóide de boca emblocados ou não em parafina, utilizando-se para isso a amplificação do DNA viral por PCR. Foram utilizados os iniciadores GP5+/GP6+, que amplificam parte da região L1 do vírus, comum a mais de 22 tipos de HPVs. Como controle positivo para as reações, foi utilizado um caso de condiloma, o qual foi positivo para os HPVs 16 e 18 na hibridização in situ. A amplificação para o HPV foi constatada apenas no controle positivo; nenhum dos casos de carcinoma epidermóide em estudo mostrou amplificação para o DNA viral. A ausência de amplificação de DNA do HPV nos casos de carcinoma epidermóide estudados sugere que esse vírus nem sempre participa do processo de carcinogênese. Essa diferença em relação a outros estudos provavelmente se dá por questões populacionais, ou mesmo de metodologia entre os diferentes trabalhos citados na literatura.

DESCRITORES: Carcinoma de células escamosas; Reação em cadeia da polimerase; Papillomavirus humano; Vírus oncogênicos.
\end{abstract}

\section{INTRODUCTION}

Human papillomaviruses (HPVs) are a family of icosahedral, non-enveloped viruses with a circular, double-stranded DNA genome of 7,500-8,000 base pairs (bp) and with a special affinity for epithelial cells. So far, more than 70 different HPV types have been defined by DNA sequence analysis. Specific types, most notably human papillomavirus (HPV) types 16, 18, and a few others, have been shown to cause the majority of cervical cancers and their high-grade precursor lesions. Infection with these
HPV types are considered as "high risk" infections ${ }^{29}$ and the viral DNA is often integrated into the host genome. The viral oncoproteins E6 and E7 bind to the products of tumour suppressor genes p53 and $\mathrm{Rb} 1$, respectively, modifying or inactivating their normal functions, resulting in deregulation of the cell cycle with loss of control in crucial cellular events, such as DNA replication, DNA repair and apoptosis ${ }^{23,28,30}$.

HPV 16, 18, and a number of additional HPV types have been found in about $95 \%$ of all speci-

\footnotetext{
* PhD, Assistant Professor, Department of Pathology, Health Science Center, Federal University of Santa Catarina.

** PhD, Associate Professor, Department of Oral Pathology, School of Dentistry, University of São Paulo.
} 
Rivero ERC, Nunes FD. HPV in oral squamous cell carcinomas of a Brazilian population: amplification by PCR. Braz Oral Res 2006;20(1):21-4.

mens of cervix cancer throughout the world ${ }^{29}$. However, the association between HPV and oral squamous cell carcinomas (OSCCs) is still unclear and the results pertaining to that association have been contradictory. The reported prevalence of HPV DNA in oral cancer tissue has varied from 0 to $100 \%{ }^{15,16,29}$.

Diagnosis of HPV is based on the use of molecular tools. These methods can involve direct hybridization with complementary DNA probes, such as Southern blotting or in situ hybridization; signal amplification, such as the hybrid capture method; or target nucleic acid amplification by the polymerase chain reaction $(\mathrm{PCR})^{5}$. The PCR is considered the most sensitive method for the detection of HPV DNA in clinical specimens s, $^{8,911}$. The PCR can be performed using type-specific PCR primers for individual HPV genome or general primers for different viruses $\mathrm{DNA}^{2,8,9,22}$. The aim of this study was to investigate the incidence of HPV infection in OSCC by using the PCR technique with consensus primers designed to amplify HPV DNA from the L1 gene of multiple HPV genotypes.

\section{MATERIAL AND METHODS}

A total of 40 cases of OSCC were used in this study. A set of 23 specimens was taken from formalin-fixed, paraffin-embedded tissues from the files of the Oral Pathology Department, School of Dentistry, University of São Paulo (São Paulo, SP), and from the archives of the Luxemburgo Hospital (Belo Horizonte, MG) and Araújo Jorge Hospital (Goiânia, GO). The other 17 cases were obtained from fresh tissues of patients attending the Head and Neck surgery service, Clinical Hospital, University of São Paulo (São Paulo, SP). The tumor's primary sites included lip (20 cases), tongue (14 cases), gingiva (3 cases), floor of mouth (2 cases) and palate ( 1 case). The mean patient age was 57 years (range 19-78), and comprised 32 men and 8 women.

\section{Extraction of DNA}

Before DNA extraction, sections of $10 \mu \mathrm{m}$ were obtained from formalin-fixed, paraffin-embedded tissues (PET) and subjected to deparaffinization and rehydration.

DNA extraction was performed according to Neves et al. ${ }^{17}$ (2002). PET samples were first digested with proteinase $\mathrm{K}$ during 3-5 days at 55$60^{\circ} \mathrm{C}$; fresh tissues were digested during one day. After proteinase $\mathrm{K}$ inactivation, the microtubes containing lysed OSCC tissues received $200 \mu 1$ of an ammonium acetate solution $(4 \mathrm{M})$ for protein precipitation. Additionally, tubes were vortexed for 20 seconds under high speed, incubated on ice for 5 minutes, and centrifuged at 13,000 x g for 3 minutes. The supernatant containing the DNA was transferred to another tube, where $600 \mu 1$ of isopropanol were added, and centrifuged at $16,000 \times \mathrm{g}$ for 5 minutes. The DNA pellet was washed in $70 \%$ ethanol and centrifuged at $16,000 \mathrm{xg}$ for $1 \mathrm{~min}$ ute. The supernatant was discarded. Samples were dried and the DNA was dissolved in 30-50 $\mu 1$ of TE solution (Tris- $\mathrm{HCl} 10 \mathrm{mM}, \mathrm{pH} 7.4$ and EDTA $1 \mathrm{mM}, \mathrm{pH} 8)$.

\section{Polymerase chain reaction}

DNA integrity and absence of PCR inhibitors were tested by amplification of exon 15 (166 bp amplicon) of the human adenomatous polyposi coli (APC) gene. Only samples with a visible APC band in the gel were included in this study.

PCR for HPV DNA amplification was performed with a set of general primers, GP5+/GP6+, aligned with corresponding sequences of the $\mathrm{L} 1$ region of 23 mucosotropic HPV genotypes (including HPV 6, $11,16,18,31$ and 33$)^{2}$. A PCR product of approximately $150 \mathrm{bp}$ was produced. Amplifications were carried out in a total volume of $25 \mu 1$, with a final concentration of $2 \mathrm{U}$ of Taq polymerase (Invitrogen, Carlsbad, CA, USA), $10 \times$ PCR buffer (Tris-HCL $200 \mathrm{mM}, \mathrm{pH} 8.4$; KCl $500 \mathrm{mM}), 0.3 \mathrm{mM}$ of dNTP (2'-deoxinucleotide 5'-triphosphate, dATP, dTTP, dCTP, dGTP) (Invitrogen, Carlsbad, CA, USA), $4 \mathrm{mM}$ of $\mathrm{MgCl}_{2}$, and $500 \mathrm{pM}$ of each primer. The PCR cycling conditions were pretreatment at $94^{\circ} \mathrm{C}$ for 3 minutes, followed by 35 cycles of denaturation at $94^{\circ} \mathrm{C}$ for 1 minute, annealing for 50 seconds at $42^{\circ} \mathrm{C}$, and extension at $72^{\circ} \mathrm{C}$ during 1 minute followed by an additional 7 minutes at $72{ }^{\circ} \mathrm{C}$.

Each PCR experiment was run with a negative control (sterile water in place of DNA) and a positive control, a case of condyloma, obtained from PET, which was positive for the HPV 16 and 18 as demonstrated by in situ hybridization, and by the PCR. Positive controls always produced amplimers of the correct size.

The PCR products were analyzed by running a $2 \%$ agarose electrophoretic gel containing ethidium bromide $(0.5 \mathrm{~g} / \mathrm{ml})$ and visualized under ultraviolet illumination. A low DNA mass ladder was used as a base-pair molecular weight pattern (Low DNA Mass Ladder, Invitrogen). 
Rivero ERC, Nunes FD. HPV in oral squamous cell carcinomas of a Brazilian population: amplification by PCR. Braz Oral Res 2006;20(1):21-4.

\section{RESULTS}

HPV was amplified in the positive-control in all reactions (viral DNA of a condyloma case). However, HPV amplification was not observed in any of the 40 OSCC specimens. All samples presented exon 15 (166 bp amplicon) amplification of the human adenomatous polyposi coli (APC) gene.

\section{DISCUSSION}

The pathogenesis of OSCC involves recognized carcinogens as tobacco and/or alcohol in intra-oral cancers, and sun exposure in lip cancers. Other factors, including viruses, may nevertheless be implicated in oral carcinogenesis ${ }^{20,21}$, mainly when in conjunction with the carcinogens present in tobacco ${ }^{10}$. Recent reports have shown that a specific subset of head and neck squamous cell carcinomas, the oropharyngeal carcinoma, is highly related to "high risk" HPVs ${ }^{4}$.

The role of HPV in oral carcinogenesis has been extensively investigated ${ }^{1,3,6,12-16,18,19,23-27}$. In the present work the complete absence of DNA HPV in OSCC was not expected. To ascertain the presence or absence of HPV DNA, we chose the PCR assay, which is considered the most sensitive method for the detection of HPV DNA in clinical specimens ${ }^{5,16}$, using a consensus primer, Gp5+/Gp6+, described by de Roda Husman et al. ${ }^{2}$ (1995). General or consensus primer-mediated PCR assay have been developed to screen for a broad spectrum of HPV types using a single PCR reaction. The Gp5+/Gp6+ primer amplifies a region of $150 \mathrm{bp}$ from the conserved $\mathrm{L} 1$ open reading frame (ORF). The $\mathrm{L} 1$ region is common to 23 mucosotropic HPV genotypes, including HPV 16 and 18, the most commonly detected in oral lesions ${ }^{4,6,15,18,19,26}$. Inclusion of a positive control in the PCR reaction is very important to rule out the possibility of false negatives; so is the negative control, to detect any possibility of false positive results by contamination during the PCR procedure. In the present work a case of condyloma, positive for HPV 16 and 18 by in situ hybridization, was used as a positive control, and all experiments produced amplimers of the cor-

\section{REFERENCES}

1. Correnti M, Rivera H, Cavazza ME. Detection of human papillomaviruses of high oncogenic potential in oral squamous cell carcinoma in a Venezuelan population. Oral Dis 2004;10(3):163-6. rect size. Finally, to rule out any non-amplifiable samples, an additional PCR for the APC gene was carried out, and all cases showed amplification.

A low prevalence of HPV in OSCC using consensus primers has been reported ${ }^{7,13,14}$, as well as when using specific primers for HPV 6, 11, 16 and $18^{25}$. To some authors the role of chemical carcinogens seems to be more important than HPV infection in the genesis of that cancer ${ }^{14}$ and the occasional HPV DNA in OSCC tissue specimens may be the result of an incidental HPV colonization of oral mucosa, rather than of viral infection ${ }^{7}$.

According to Matzow et al. ${ }^{13}$ (1998), the possible integration of viral DNA into the cell genome, which represents a common event in malignant tumors, can cause deletions of the L1 ORF, to which most consensus primers are directed, leading to false negative PCR results. However, these authors used the Gp5+/Gp6+ to the L1 ORF, and the $\mathrm{CPI} / \mathrm{CPIIG}$ to the $\mathrm{E} 1$ region, and obtained negative results for both pairs of primers in OSCC. It is important to point out that the most commonly deleted part of the viral genome, during the viral DNA integration into the host-cell DNA, is the E2, E4, E5 and L2 coding sequences ${ }^{30}$.

\section{CONCLUSIONS}

Absence of HPV DNA amplification by PCR in the OSCCs studied cases suggests that this virus not always plays a role in the carcinogenesis process. Discrepant results found in the literature can be explained by methodological and technical differences in detecting and typing of HPV, as well as by geographic and ethnical differences that certainly influence the carcinogenesis process.

\section{ACKNOWLEDGMENTS}

We wish to thank Professor Martinho Campolina Horta (PhD), Professor Eliete da Silva Guerra (PhD) and Professor Alberto Ferraz (PhD) for the cases used in this study.

We would also like to thank FAPESP (The State of São Paulo Research Foundation), Grant no. 01/03774-0, for funding.

2. de Roda Husman AM, Walboomers JM, van den Brule AJ, Meijer CJ, Snijders PJ. The use of general primers GP5 and GP6 elongated at their 3' ends with adjacent highly conserved sequences improves human papillomavirus detection by PCR. J Gen Virol 1995;76(Pt 4):1057-62. 
Rivero ERC, Nunes FD. HPV in oral squamous cell carcinomas of a Brazilian population: amplification by PCR. Braz Oral Res 2006;20(1):21-4.

3. Elamin F, Steingrimsdottir H, Wanakulasuriya S, Johnson N, Tavassoli M. Prevalence of human papillomavirus infection in premalignant and malignant lesions of the oral cavity in U.K. subjects: a novel method of detection. Oral Oncol 1998;34(3):191-7.

4. Gillison ML, Koch WM, Capone RB, Spafford M, Westra $\mathrm{WH}, \mathrm{Wu} \mathrm{L}$, et al. Evidence for a causal association between human papillomavirus and a subset of head and neck cancers. J Natl Cancer Inst 2000;92(9):709-20.

5. Hubbard RA. Human papillomavirus testing methods. Arch Pathol Lab Med 2003;127(8):940-5.

6. Ibieta BR, Lizano M, Fras-Mendivil M, Barrera JL, Carrillo A, Ma Ruz-Godoy L, et al. Human papilloma virus in oral squamous cell carcinoma in a Mexican population. Oral Surg Oral Med Oral Pathol Oral Radiol Endod 2005;99(3):311-5.

7. Kansky AA, Poljak M, Seme K, Kocjan BJ, Gale N, Luzar $\mathrm{B}$, et al. Human papillomavirus DNA in oral squamous cell carcinomas and normal oral mucosa. Acta Virol 2003;47(1):11-6.

8. Kleter B, van Doorn LJ, Schrauwen L, Molijn A, Sastrowijoto S, ter Schegget J, et al. Development and clinical evaluation of a highly sensitive PCR-reverse hybridization line probe assay for detection and identification of anogenital human papillomavirus. J Clin Microbiol 1999;37(8):250817.

9. Kleter B, van Doorn LJ, ter Schegget J, Schrauwen L, van Krimpen K, Burger M, et al. Novel short-fragment PCR assay for highly sensitive broad-spectrum detection of anogenital human papillomaviruses. Am J Pathol 1998;153(6):1731-9.

10. Koppikar P, de Villiers EM, Mulherkar R. Identification of human papillomaviruses in tumors of the oral cavity in an Indian community. Int J Cancer 2005;113(6):946-50.

11. Kosel S, Burggraf S, Mommsen J, Engelhardt W, O1gemoller B. Type-specific detection of human papillomaviruses in a routine laboratory setting - improved sensitivity and specificity of PCR and sequence analysis compared to direct hybridisation. Clin Chem Lab Med 2003;41(6):78791.

12. Kozomara R, Jovic N, Magic Z, Brankovic-Magic M, Minic V. p53 mutations and human papillomavirus infection in oral squamous cell carcinomas: correlation with overall survival. J Craniomaxillofac Surg 2005;33(5):342-8.

13. Matzow T, Boysen M, Kalantari M, Johansson B, Hagmar B. Low detection rate of HPV in oral and laryngeal carcinomas. Acta Oncol 1998;37(1):73-6.

14. Miguel RE, Villa LL, Cordeiro AC, Prado JC, Sobrinho JS, Kowalski LP. Low prevalence of human papillomavirus in a geographic region with a high incidence of head and neck cancer. Am J Surg 1998;176(5):428-9.

15. Miller CS, Johnstone BM. Human papillomavirus as a risk factor for oral squamous cell carcinoma: a metaanalysis, 1982-1997. Oral Surg Oral Med Oral Pathol Oral Radiol Endod 2001;91(6):622-35.
16. Miller CS, White DK. Human papillomavirus expression in oral mucosa, premalignant conditions, and squamous cell carcinoma: a retrospective review of the literature. Oral Surg Oral Med Oral Pathol Oral Radiol Endod 1996;82(1):57-68

17. Neves AC, Rivero ERC, Silva-Valenzuela MG, Sousa SCOM, Nunes FD. Método de extração de DNA de material de arquivo pelo acetato de amônio e pelo isopropanol [resumo Pb329]. Pesqui Odontol Bras 2002;16:210.

18. Ostwald C, Muller P, Barten M, Rutsatz K, Sonnenburg M, Milde-Langosch K, et al. Human papillomavirus DNA in oral squamous cell carcinomas and normal mucosa. J Oral Pathol Med 1994;23(5):220-5.

19. Premoli-De-Percoco G, Ramirez JL. High risk human papillomavirus in oral squamous carcinoma: evidence of risk factors in a Venezuelan rural population. Preliminary report. J Oral Pathol Med 2001;30(6):355-61.

20. Scully C. Oncogenes, tumor suppressors and viruses in oral squamous carcinoma. J Oral Pathol Med 1993;22(8):337-47.

21. Scully C. Oral cancer; the evidence for sexual transmission. Br Dent J 2005;199(4):203-7.

22. Snijders PJ, van den Brule AJ, Schrijnemakers HF, Snow G, Meijer CJ, Walboomers JM. The use of general primers in the polymerase chain reaction permits the detection of a broad spectrum of human papillomavirus genotypes. J Gen Virol 1990;71(Pt 1):173-81.

23. Tommasino M, Crawford L. Human papillomavirus E6 and E7: proteins which deregulate the cell cycle. Bioessays 1995;17(6):509-18.

24. Uobe K, Masuno K, Fang YR, Li LJ, Wen YM, Ueda Y, et al. Detection of HPV in Japanese and Chinese oral carcinomas by in situ PCR. Oral Oncol 2001;37(2):146-52.

25. van Rensburg EJ, Engelbrecht S, van Heerden WF, Raubennheimer EJ, Schoub BD. Human papillomavirus DNA in oral squamous cell carcinomas from an African population sample. Anticancer Res 1996;16(2):969-73.

26. Woods KV, Shillitoe EJ, Spitz MR, Schantz SP, Adler-Storthz K. Analysis of human papillomavirus DNA in oral squamous cell carcinomas. J Oral Pathol Med 1993;22(3):101-8.

27. Zhang ZY, Sdek P, Cao J, Chen WT. Human papillomavirus type 16 and 18 DNA in oral squamous cell carcinoma and normal mucosa. Int J Oral Maxillofac Surg 2004;33(1):71-4.

28. zur Hausen H. Immortalization of human cells and their malignant conversion by high risk human papillomavirus genotypes. Semin Cancer Biol 1999;9(6):405-11.

29.zur Hausen H. Papillomavirus infections - a major cause of human cancers. Biochem Biophys Acta 1996;1288(2):F55-78.

30. zur Hausen H. Papillomaviruses and cancer: from basic studies to clinical application. Nat Rev Cancer 2002;2(5):342-50. 